\title{
KAJIAN PERBAIKAN SUBGRADE DARI TANAH EKSPANSIF MENGGUNAKAN SPENT CATALYST RCC 15 DAN ABU BATOK KELAPA SAWIT
}

\author{
Totok Hermawan ${ }^{1}$, Syahril $^{2}$
}

1) Mahasiswa Jurusan Teknik Sipil Program Magister Terapan Politeknik Negeri Bandung Jl. Gegerkalong Hilir Ds. Ciwaruga Bandung 40012. Email: totok.hermawan90@ yahoo.com

2) Staf Pengajar Jurusan Teknik Sipil Program Magister Terapan Politeknik Negeri Bandung Jl. Gegerkalong Hilir Ds. Ciwaruga Bandung 40012. Email: syahril_polban@yahoo.com

\begin{abstract}
ABSTRAK
Hasil pengujian pada lapisan Subgrade yang dilakukan di ruas jalan tol Cisumdawu khususnya pada STA 13+500 tergolong pada jenis tanah ekspansif. Kondisi Subgrade tersebut jika tidak segera diperbaiki maka dapat mengakibatkan berbagainya jenis kerusakan pada perkerasannya. Dalam penelitian perbaikan Subgrade yang dilakukan adalah menggunakan metode stabilisasi dengan Abu Batok Kelapa Sawit dan Spent Catalyst RCC 15. Penelitian ini bertujuan untuk mengevaluasi sejauh mana pengaruh penambahan Abu Batok Kelapa Sawit dan Spent Catalyst RCC 15 terhadap kembang susut dan daya dukung sebagai lapisan Subgrade konstruksi perkerasan ruas jalan tol Cisumdawu. Penelitian ini menghasilkan beberapa kesimpulan yaitu (1) Terjadi penurunan nilai untuk kadar air optimum, Plasticity Index, Swelling Potential dan Swelling Pressure. (2) Terjadi Kenaikan nilai untuk Berat Isi Kering, CBR Unsoaked, CBR Soaked, CBR Peram, Permeabilitas, Ca-dd dan K-dd. (3) Tercapainya campuran bahan stabilisasi yang dapat digunakan sebagai perbaikan Subgrade pada tanah ekspansif untuk standar minimal Subgrade lapisan perkerasan jalan. (4) Belum tercapainya nilai yang optimum pada campuran bahan stabilisasi yang digunakan terhadap perubahan nilai karakteristik Subgrade. (5) Hasil pengujian secara statistik yang dilakukan didapatkan suatu hubungan yang yang berarti secara statistic.
\end{abstract}

Kata Kunci : $\quad$ Lapisan Subgrade, Stabilisasi, Abu Batok Kelapa Sawit, Spent Catalyst RCC 15, karakteristik Subgrade

\section{Pendahuluan}

Pembangunan jalan Tol Cisumdawu ini direncanakan sebagai upaya Pemerintah Pusat dan Propinsi Jawa Barat untuk pengembangan wilayah di setiap daerah yang terhubung oleh jalan tol Cisumdawu, khususnya dalam mendukung PKN di Cirebon dan mendukung Pembangunan Bandara Internasional Kertajati di Majalengka. Berdasarkan penjelasan mengenai peranan dari jalan Tol Cisumdawu yang sangatlah penting, maka untuk kondisi struktur perkerasan khususnya pada lapisan Subgrade yang ada di sepanjang ruas jalan tol Cisumdawu haruslah stabil.
Hasil pengujian pada lapisan Subgrade yang dilakukan di ruas jalan tol Cisumdawu khususnya pada STA $13+500$, lapisan Subgrade tersebut tergolong pada jenis tanah ekspansif. Kondisi Subgrade tersebut jika tidak segera diperbaiki maka dapat mengakibatkan berbagainya jenis kerusakan pada perkerasannya. Dalam penelitian ini perbaikan yang dilakukan adalah menggunakan metode stabilisasi Subgrade dengan Abu Batok Kelapa Sawit dan Spent Catalyst RCC 15.

Penelitian ini memiliki beberapa tujuan yaitu (1) Mendapatkan seberapa besar pengaruh penambahan Abu Batok Kelapa Sawit (ABKS) dan Spent Catalyst RCC 15 (SC) terhadap 
kembang susut (parameternya adalah Swelling Potential, Swelling Pressure, Plasticity Index, Tingkat Keaktifan) dan daya dukung (parameternya adalah CBR) sebagai lapisan Subgrade konstruksi perkerasan ruas jalan tol Cisumdawu pada STA $13+500$.

Memperoleh campuran bahan stabilisasi yang dapat digunakan sebagai perbaikan Subgrade pada tanah ekspansif untuk standar minimal Subgrade lapisan perkerasan jalan dan (3) Mendapatkan nilai campuran bahan stabilisasi yang optimum yang dapat memberikan perubahan terbesar terhadap perbaikan Subgrade yang dilakukan.

\section{Studi Pustaka}

\section{II.1 Subgrade}

Menurut Harianto (2003) Subgrade (Lapisan tanah dasar) adalah bagian dari permukaan badan jalan yang dipersiapkan untuk perletakan konstruksi di atasnya yaitu konstruksi perkerasan. Kekuatan dan keawetan maupun tebal dari lapisan konstruksi perkerasan jalan sangat tergantung dari sifat-sifat dan daya dukung Subgrade ini, karena Subgrade berfungsi sebagai penerima beban lalu lintas yang telah disalurkan/disebarkan oleh konstruksi perkerasan. Ditinjau dari muka tanah asli, maka lapisan tanah dasar dibedakan atas:

- Subgrade, tanah galian

- Subgrade, tanah timbunan

- Subgrade, tanah asli

Fungsi lapisan Subgrade adalah menerima tekanan akibat beban lalu lintas yang ada di atasnya sehingga harus mempunyai kapasitas dukung yang optimal dan mampu menerima gaya akibat beban lalu lintas tanpa mengalami perubahan dan kerusakan yang berarti. Bahwa kekuatan dan keawetan konstruksi perkerasan jalan sangat tergantung dari sifat-sifat dan daya dukung Subgradenya.

Untuk sedapat mungkin mencegah timbulnya permasalahan pada Subgrade, maka Subgrade yang ada harus memiliki standar minimal sebagai material lapisan perkerasan jalan. Berikut pada Tabel 1 dijelaskan mengenai standar minimal material Subgrade yang digunakan sebagai lapisan perkerasan jalan

Tabel 1. Standar Minimal Material Subgrade Yang Digunakan Sebagai Lapisan Perkerasan Jalan

\begin{tabular}{|l|c|c|l|}
\hline Parameter & $\begin{array}{c}\text { Standar } \\
\text { Minimal }\end{array}$ & Satuan & \multicolumn{1}{|c|}{ Sumber } \\
\hline $\begin{array}{l}\text { Plasticity } \\
\text { Indeks (PI) }\end{array}$ & $<18$ & $\%$ & $\begin{array}{l}\text { Holz \& Gribbs } \\
(1956)\end{array}$ \\
\hline $\begin{array}{l}\text { Tingkat } \\
\text { Keaktifan }\end{array}$ & $\leq 1,25$ & - & Pd T-10-2005-B \\
\hline CBR & $\geq 6$ & $\%$ & $\begin{array}{l}\text { Manual Desain } \\
\text { Perkerasan }\end{array}$ \\
\hline $\begin{array}{l}\text { Swelling } \\
\text { Potential }\end{array}$ & $<5$ & $\%$ & Pd T-10-2005-B \\
\hline $\begin{array}{l}\text { Swelling } \\
\text { Pressure }\end{array}$ & $<4$ & $\mathrm{Kg} / \mathrm{cm}^{2}$ & $\begin{array}{l}\text { Yuliet,dkk, } \\
2011\end{array}$ \\
\hline
\end{tabular}

\section{II.2 Tanah Ekspansif}

Menurut Seta (2010) bahwa tanah ekspansif adalah tanah yang mempunyai sifat kembang susut yang besar, sifat kembang susut ini sangat dipengaruhi oleh kandungan air yang ada di dalam tanah tersebut. Jika kandungan airnya banyak maka tanah tersebut akan mengembang dan kekuatan daya dukungnya akan berkurang demikian sebaliknya.

Menurut Hardiyatmo (2006) bahwa tanah mengembang atau disebut juga dengan expansive soil adalah tanah yang memiliki ciriciri kembang susut yang besar, mengembang pada musim hujan dan menyusut pada musim kemarau. Sifat kembang susut yang demikian bisa menimbulkan kerusakan pada bangunan. Kerusakan akibat tanah ekspansif diantaranya retak-retak, pengangkatan tanah atau cembungan pada perkerasan jalan, penurunan perkerasan jalan, longsor, dll.

KAJIAN PERBAIKAN SUBGRADE DARI TANAH EKSPANSIF MENGGUNAKAN SPENT CATALYST RCC 15 DAN ABU BATOK KELAPA SAWIT Totok Hermawan, Syahril 


\section{II.3 Metode Mengidentifikasi Ekspansif}

A. Identifikasi Tidak Langsung

1) Nilai indeks plastisitas, Shrinkage Limit.

Berdasarkan Pd T-10-2005-B menyatakan bahwa untuk menentukan jenis tanah ekspansif dapat menggunakan dua parameter yaitu PI (Plasticity Index) dan SL (Shrinkage Limit), berdasarkan Tabel 2 berikut ini:

Tabel 2. Kriteria Tanah Ekspansif Berdasarkan IP dan SL

\begin{tabular}{|c|c|c|}
\hline PI (\%) & SL (\%) & Degree of Ekspansion \\
\hline$<12$ & $<15$ & Low \\
\hline $12-23$ & $15-30$ & Medium \\
\hline $23-32$ & $30-40$ & High \\
\hline$>32$ & $>40$ & Very High \\
\hline
\end{tabular}

2) Tingkat Keaktifan

Berdasarkan Pd T-10-2005-B bahwa Batas Atterberg dan fraksi lempung dapat dikombinasikan menjadi satu parameter yang dinamakan tingkat keaktifan (activity). Berikut dijelaskan perhitungan untuk menentukan tingkat keaktifan suatu tanah:

$\mathrm{AC}=\mathrm{PI} /(\mathrm{CF}-\mathrm{n})$

Dimana:

$$
\begin{array}{ll}
\mathrm{AC} & =\text { Aktivitas (tanpa satuan) } \\
\mathrm{PI} & =\text { Plasticity Index }(\%) \\
\mathrm{CF} & =\text { Lempung lolos saringan no. } 200(\%) \\
\mathrm{n} & =\text { Berharga } 5 \text { (Subgrade) }
\end{array}
$$

Jika dikorelasikan dengan potensi pengembangan, maka tanah lempung dapat dibagi menjadi tiga kelas berdasarkan tingkat keaktifannya yaitu dari tingkat tidak aktif, normal dan aktif seperti yang diperlihatkan pada Tabel 3 berikut ini:
Tabel 3. Korelasi Nilai Aktivity dengan Potensi Pengembangan

\begin{tabular}{|c|c|c|}
\hline AC & $\begin{array}{c}\text { Tingkat } \\
\text { Keaktifan }\end{array}$ & $\begin{array}{c}\text { Potensi } \\
\text { Pengembangan }\end{array}$ \\
\hline$<0,75$ & Tidak aktif & Rendah \\
\hline $0,75<\mathrm{AC}<1,25$ & Normal & Sedang \\
\hline$>1,25$ & Aktif & Tinggi \\
\hline
\end{tabular}

\section{B. Identifikasi Secara Langsung}

Identifikasi secara langsung dilakukan melalui pengukuran pengembangan secara langsung, baik terhadap contoh tanah terganggu maupun tidak terganggu. Nilai indeks pengembangan hingga pembulatan terkecil dapat dihitung dengan menggunakan persamaan berikut:

$\mathrm{EI}=100 \Delta \mathrm{H} \times \mathrm{F}$

Dengan pengertian:

EI : indeks pengembangan

$\Delta \mathrm{H}$ : persentase pengembangan

F : : Lempung lolos saringan no. $200(\%)$

Potensi pengembangan tanah juga telah dikelompokkan berdasarkan nilai indeks pengembangannya yaitu seperti pada Tabel 4 berikut ini:

Tabel 4. Korelasi nilai indeks pengembangan dengan potensi pengembangan

\begin{tabular}{|c|c|}
\hline EI & Potensi pengembangan \\
\hline $0-20$ & Sangat rendah \\
$21-50$ & Rendah \\
$51-90$ & Sedang \\
$91-130$ & Tinggi \\
\hline
\end{tabular}

Sumber: Pd T-10-2005-B

3) Identifikasi Mineral Lempung

Identifikasi mineral lempung merupakan faktor utama yang mengontrol perilaku tanah

KAJIAN PERBAIKAN SUBGRADE DARI TANAH EKSPANSIF MENGGUNAKAN SPENT CATALYST RCC 15 DAN ABU BATOK KELAPA SAWIT Totok Hermawan, Syahril 
ekspansif. Didalam uji mineral lempung ada beberapa cara yang yang biasa dipergunakan, yaitu antara lain:

\section{- $\quad$ Difraksi Sinar X (X-Ray Difrakction)}

Merupakan metoda yang paling terkenal dan paling sering dipergunakan untuk menentukan perbandingan dari berbagai mineral yang terdapat pada lempung,

\section{- $\quad$ Analisa Kimia}

Analisa ini digunakan sebagai pelengkap dari metoda sinar X.

\section{- Mikroskop Elektron}

Kegunaan dari metode ini adalah untuk menentukan komposisi mineral tekstur dan struktur mineral.

\section{Spent Catalyst RCC 15}

Spent Catalyst Residium catalytic cracking 15 (RCC-15) adalah merupakan limbah dari penyulingan minyak tanah, dimana Spent Catalyst RCC 15 mempunyai sifat Pozzolanic dan terutama terdiri dari oksidasi silica, alumunia, ferro dan lain-lain (Sudirja, 2008). Berikut pada Gambar 1 ditunjukan karakteristik (warna, tekstur) dari Spent Catalyst RCC 15.

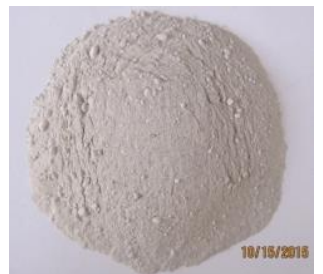

Gambar 1. Karakteristik (Warna/Tekstur) Spent Catalyst RCC 15

\section{Abu Batok Kelapa Sawit}

Abu batok kelapa sawit (ABKS) adalah limbah padat yang berasal dari pembakaran cangkang kelapa sawit yang dipergunakan sebagai bahan untuk menghasilkan uap pada proses penggilingan minyak sawit. Berikut pada Gambar 2 ditunjukan karakteristik (warna, tekstur) dari Abu Batok Kelapa Sawit.

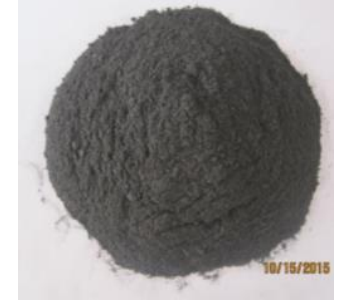

Gambar 2. Karakteristik (Warna/Tekstur) Abu Batok Kelapa Sawit

\section{Pengujian Tanah}

Pengujian pada sifat-sifat tanah terdiri dari pengujian sifat-sifat fisik (physical properties) dan pengujian sifat-sifat teknis (engineering properties). Pengujian sifat-sifat fisik antara lain mengenai pengujian kadar air, berat jenis, pengujian batas-batas atterberg, dan pengujian analisa hydrometer sedangkan didalam pengujian sifat-sifat teknis antara lain terdiri dari pengujian pemadatan, pengujian CBR, dan pengujian swelling.

\section{A. Pengujian Sifat-Sifat Fisik Tanah \\ 1) Pengujian Kadar Air}

Menurut SNI 03-1965 kadar air tanah adalah perbandingan antara berat air yang terkandung dalam tanah dengan berat butir tanah tersebut yang dinyatakan dalam persen.

\section{2) Pengujian Berat Isi}

Menurut SNI 03-1964 berat isi tanah adalah perbandingan antara berat tanah dengan volumenya dalam keadaan asli di lapangan. Semakin besar berat isi kering tanah maka tingkat kepadatannya pun tinggi.

3) Pengujian Berat Jenis

Menurut SNI 03-1964 berat jenis tanah atau Specific Gravity (Gs) adalah perbandingan antara berat butir tanah dengan berat air suling dengan isi yang sama pada suhu tertentu. Nilai dari berat jenis akan berpengaruh ke beberapa hal seperti kekuatan tanah, berat sendiri tanah, dll.

\section{4) Pengujian Atterberg Limits}

Batas-batas Konsistensi Tanah (Atterberg limit) yang dikenal adalah batas cair, batas plastis dan batas susut.

KAJIAN PERBAIKAN SUBGRADE DARI TANAH EKSPANSIF MENGGUNAKAN SPENT CATALYST RCC 15 DAN ABU BATOK KELAPA SAWIT Totok Hermawan, Syahril 


\section{5) Pengujian Analisa Ukuran Butir Tanah}

Ukuran butir tanah menjadi dasar untuk pemberian atau klasifikasi nama kepada macammacam tanah tertentu. Sesuai dengan jenis ukuran butir tanah, cara menganalisa ukuran butir tanah dapat dilakukan dengan 3 (tiga) cara yaitu analisa saringan, analisa hidrometer, analisa gabungan.

\section{B. Pengujian Sifat-Sifat Mekanis Tanah \\ 1) Pengujian Pemadatan}

Pemadatan adalah suatu proses di mana udara pada pori-pori tanah dikeluarkan dengan salah satu cara mekanis yang digunakan untuk memadatkan tanah. Tujuan dilakukannya pengujian pemadatan dilaboratorium adalah untuk menentukan berat isi kering maksimum dan kadar air optimum tanah

\section{2) Pengujian CBR}

CBR digunakan selain untuk menilai kekuatan tanah dasar, CBR juga dipakai sebagai dasar untuk menentukan tebal lapisan dari suatu perkerasan.

\section{3) Pengujian Swelling Potential}

Pengujian Swelling Potential ini dilaksanakan mengacu pada ASTM D 4546-90. Presentase mengembang didefinisikan sebagai besarnya pengembangan vertikal dari suatu contoh tanah yang berada dalam oedometer (steel ring) di bawah beban vertikal sebesar $6,9 \mathrm{kN} / \mathrm{m}^{2}$

\section{4) Pengujian Swelling Pressure}

Besarnya tekanan mengembang (Swelling Pressure) dipengaruhi oleh batas cair, berat isi kering serta kadar air awal (Yuliet,dkk, 2011).

\section{Metodologi}

Tahapan yang dilakukan pada penelitian ini seperti yang ditunjukan pada Gambar 3 berikut ini:

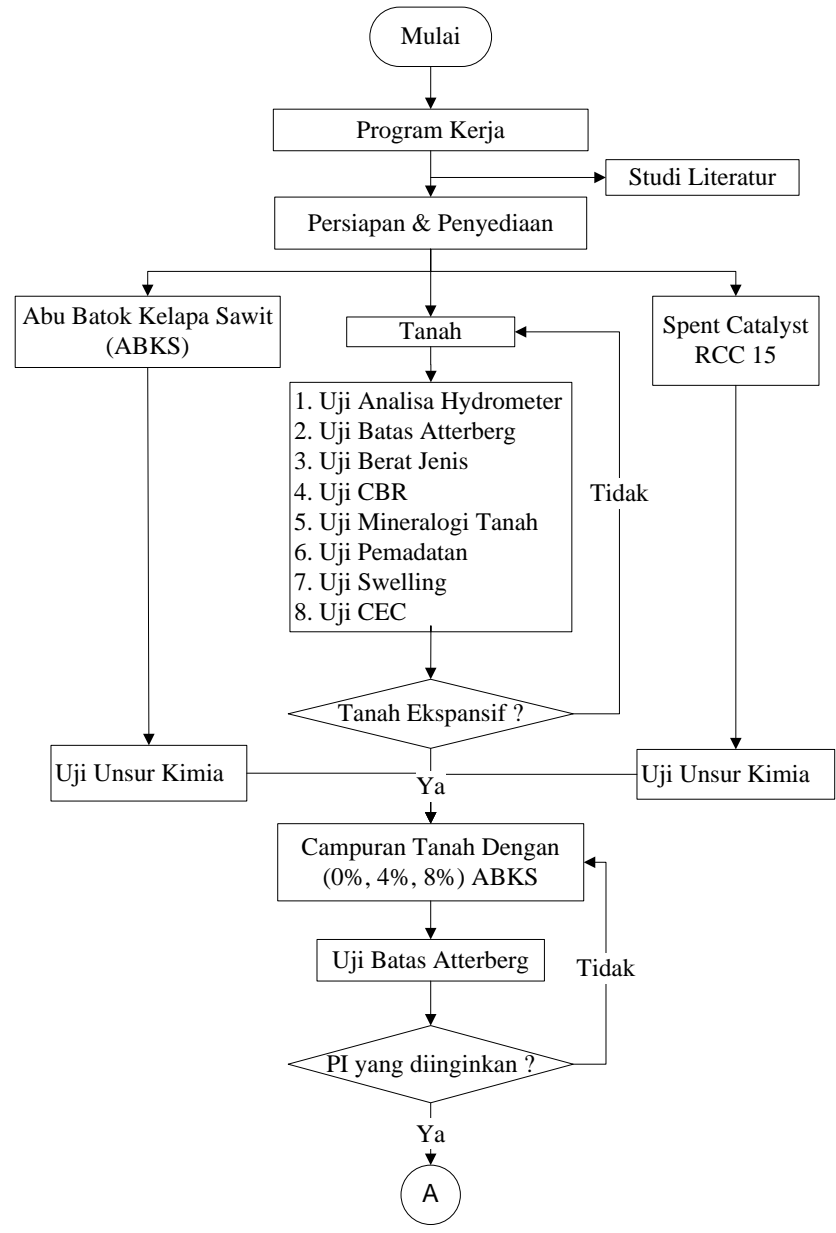

Gambar 3. Diagram Tahapan Kegiatan penelitian 


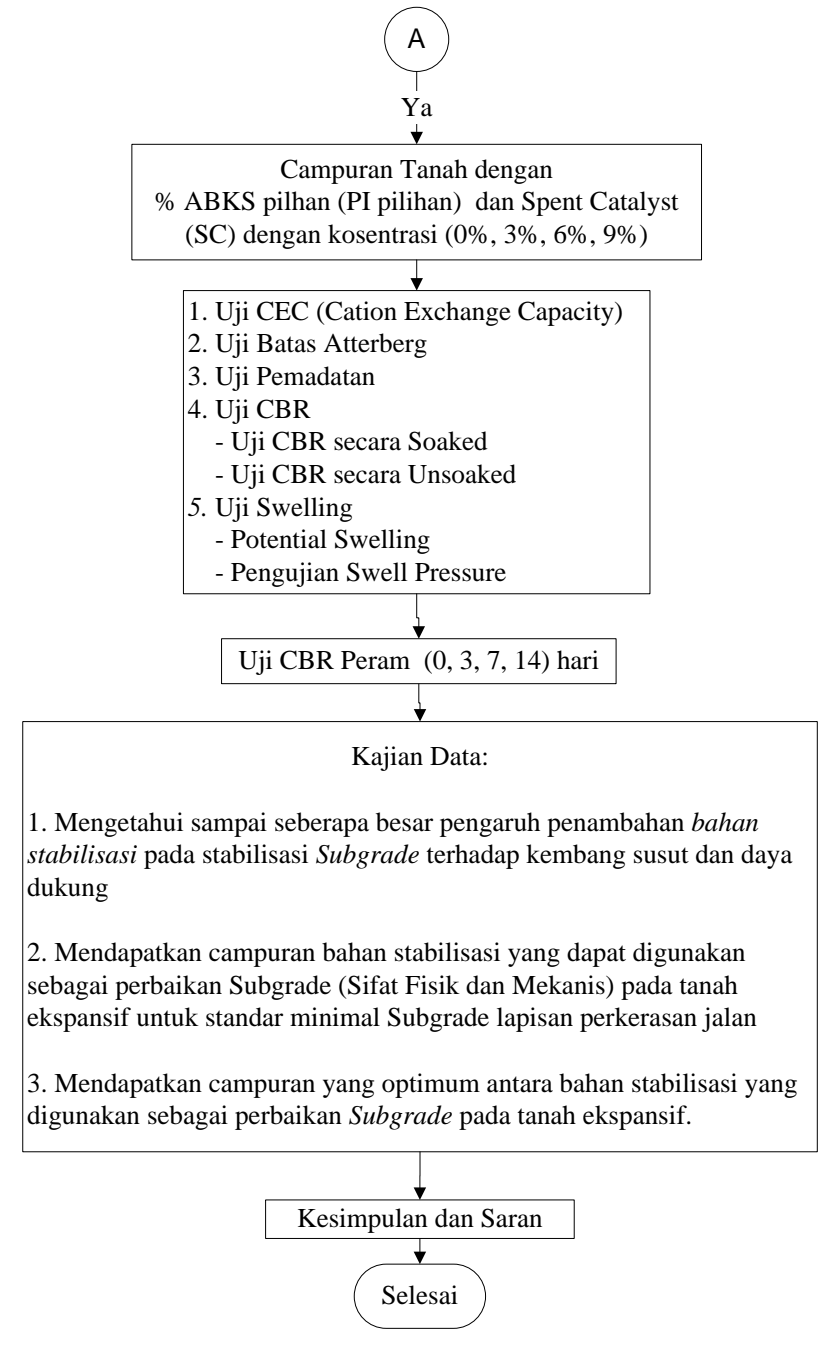

Gambar 3. Diagram Tahapan Kegiatan penelitian (Lanjutan)

Pada bagian ini dijelaskan mengenai tahapan pelaksanaan penelitian berdasarkan Flowchart Gambar 3:

\section{Pekerjaan Persiapan}

Pekerjaan persiapan meliputi pekerjaan pengambilan sampel tanah, pengambilan bahan stabilisasi (abu batok kelapa sawit dan Spent Catalyst RCC 15)

\section{Pelaksanaan Uji awal}

Uji Pendahuluan meliputi pengujian komposisi kimia (tanah dan bahan stabilisasi), pengujian sifat fisik dan sifat mekanis tanah asli (sebelum dicampur dengan bahan stabilisasi).

\section{Pelaksanaan Uji akhir}

Uji akhir meliputi pengujian komposisi kimia, pengujian sifat fisik dan sifat mekanis tanah campuran dengan bahan stabilisasi

\section{Kajian Data}

Setelah dilakukan uji akhir kemudian dilanjutkan dengan kajian data yang membahas mengenai beberapa hal yaitu:

A. Membahas terkait hasil pengujian yang dilakukan ditambah dengan pembahasan mengenai hasil pengolahan data secara statistik antara setiap pengujian yang dilakukan.

B. Membahas ketercapaian subgrade campuran berdasarkan karakteristik subgrade secara fisik, mekanis maupun kimiawi terhadap standar minimal nilai sebagai lapisan perkerasan jalan

C. Membahas mengenai pengaruh stabilisasi subgrade terhadap perkerasan jalan

\section{Hasil Penelitian dan Pembahasan 1. Hasil Penelitian}

Pada bagian ini dijelaskan mengenai hasil penelitian yang dilakukan, yaitu hasil pengujian komposisi kimia subgrade dan bahan stabilisasi maupun karakteristik subgrade (sifat fisik dan sifat mekanis) sebelum dan sesudah di campur dengan bahan stabilisasi. Berikut penjelasannya:

\section{A. Hasil pengujian dari komposisi kimia subgrade dan bahan stabilisasi}

Hasil pengujian komposisi kimia subgrade dan bahan stabilisasi seperti yang terlihat dalam Tabel 5 dan tabel 6 berikut ini:

KAJIAN PERBAIKAN SUBGRADE DARI TANAH EKSPANSIF MENGGUNAKAN SPENT CATALYST RCC 15 DAN ABU BATOK KELAPA SAWIT Totok Hermawan, Syahril 
Tabel 5. Komposisi kimia Subgrade dengan Metode CEC

\begin{tabular}{|c|c|c|c|}
\hline No. & Parameter & Satuan & Nilai CEC \\
\hline 1. & Ca-dd & $\mathrm{Me} / 100 \mathrm{~g}$ & 13,13 \\
\hline 2. & $\mathrm{Mg}-\mathrm{dd}$ & $\mathrm{Me} / 100 \mathrm{~g}$ & 6,58 \\
\hline 3. & $\mathrm{Na}-\mathrm{dd}$ & $\mathrm{Me} / 100 \mathrm{~g}$ & 1,16 \\
\hline 4. & K-dd & $\mathrm{Me} / 100 \mathrm{~g}$ & 0,37 \\
\hline
\end{tabular}

Sumber: TEKMIRA

Tabel 6. Hasil Pengujian komposisi kimia ABKS dan Spent Catalyst RCC 15

\begin{tabular}{|c|c|c|c|}
\hline \multirow{2}{*}{ No } & \multirow{2}{*}{$\begin{array}{c}\text { Komposisi } \\
\text { Kimia }\end{array}$} & SC & ABKS \\
\hline & & \multicolumn{2}{|c|}{ Kadar (\%) } \\
\hline 1 & $\mathrm{SiO}_{2}$ & 50,72 & 50,05 \\
\hline 2 & $\mathrm{Al}_{2} \mathrm{O}_{3}$ & 37,12 & 2,42 \\
\hline 4 & $\mathrm{CaO}$ & 1,12 & 8,55 \\
\hline 5 & $\mathrm{MgO}$ & 0,40 & 6,55 \\
\hline
\end{tabular}

Sumber: Balai B.P. \& P. Industri Keramik, Bandung.

\section{B. Hasil pengujian karakteristik subgrade}

1) Hasil Pengujian Karakteristik Fisik Subgrade

Berikut ini pada Tabel 7 dijelaskan hasil pengujian dari karakteristik fisik Subgrade.

Tabel 7. Hasil Pengujian Karakteristik Fisik Subgrade

\begin{tabular}{|c|l|c|c|c|}
\hline No & Index Properties & symbol & unit & Nilai \\
\hline 1 & Specific of gravity & Gs & - & 2,617 \\
\hline 2 & Water content & w & $\%$ & 42,23 \\
\hline 3 & Density & $y$ & $\begin{array}{c}\mathrm{gr} / \\
\mathrm{cm} 3\end{array}$ & 1,64 \\
\hline 4 & Atterberg limits & & & \\
\hline
\end{tabular}

\begin{tabular}{|c|c|c|c|c|}
\hline 4.1 & Plastic limit & PL & $\%$ & 28,07 \\
\hline 4.2 & Liquid limit & LL & $\%$ & 63,64 \\
\hline 4.3 & Plasticity Index & PI & $\%$ & 35,57 \\
\hline 5 & Keaktifan & $\mathrm{AC}$ & & 1,34 \\
\hline 6 & Grain size & & & \\
\hline & Gravel & $\mathrm{G}$ & $\%$ & 0,00 \\
\hline & Sand & S & $\%$ & 8,71 \\
\hline & Silt & M & $\%$ & 54,80 \\
\hline & Clay & $\mathrm{C}$ & $\%$ & 36,49 \\
\hline
\end{tabular}

Berikut ini dijelaskan secara singkat mengenai kriteria Subgrade berdasarkan karakteristik fisik tersebut:

- Berdasarkan klasifikasi type tanah menunjukkan bahwa Subgrade dengan nilai kadar air antara 40\% - 50\% digolongkan masuk kedalam golongan type tanah lempung lembek

- Berdasarkan Pd T-10-2005-B menunjukkan bahwa Subgrade dengan Plasticity Index > $32 \%$ digolongkan sebagai lempung yang mempunyai sifat pengembangan yang sangat tinggi

- Berdasarkan Pd T-10-2005-B menunjukkan bahwa Subgrade dengan AC $>1,25$ digolongkan sebagai lempung dengan keaktifan yang aktif dengan tingkat pengembangan tinggi

- Berdasarkan klasifikasi USCS dan Chen (1988) bahwa dengan harga batas cair $>60 \%$ termasuk kedalam golongan Clay High (lempung anorganik dengan plastisitas tinggi) dan memiliki tingkat pengembangan yang sangat tinggi.

- Berdasarkan Tri Hatmoko,dkk (2007) menunjukan bahwa subgrade dengan nilai prosentase lewat saringan no.200 antara 6090\% digolongkan sebagai tanah lanau kelempungan yang memiliki derajat pengembangan tinggi. 
2) Hasil Pengujian Karakteristik Mekanis Subgrade

Berikut ini pada Tabel 8 dijelaskan hasil pengujian dari karakteristik mekanis Subgrade.

Tabel 8. Hasil Pengujian Karakteristik Mekanis Subgrade

\begin{tabular}{|l|c|c|}
\hline Technical Properties & unit & Nilai \\
\hline CBR UnSoaked & $\%$ & 3,39 \\
\hline Swelling Potential & $\%$ & 6,37 \\
\hline Swelling Pressure & $\mathrm{Kg} / \mathrm{cm} 2$ & 4,41 \\
\hline
\end{tabular}

Berikut ini dijelaskan secara singkat mengenai kriteria Subgrade berdasarkan karakteristik mekanis tersebut:

- Berdasarkan manual desain perkerasan jalan (2012) untuk nilai CBR sebesar 3,39\% > 3\% harus melakukan peningkatan tebal tanah dasar minimum sebesar $300 \mathrm{~mm}$, jika dikorelasikan terhadap besarnya nilai potensi pengembangan (Swelling Potential) sebesar $6,37 \%>5 \%$, maka Subgrade yang ada harus dilakukan peningkatan tebal tanah dasar minimum sebesar $600 \mathrm{~mm}$, kondisi tersebut pada lalu lintas lajur desain > 4 juta CESA dengan umur rencana 40 tahun

- Berdasarkan Pd T-10-2005-B menunjukkan bahwa Subgrade dengan Swelling Potential $\geq$ $5 \%$ digolongkan sebagai subgrade yang memiliki derajat ekspansif yang tinggi

- Menurut Yuliet,dkk (2011) menunjukkan bahwa Subgrade dengan Swelling Pressure $\geq$ $4 \mathrm{~kg} / \mathrm{cm} 2$ digolongkan sebagai subgrade yang memiliki tingkat pengembangan tinggi

\section{Hasil Pengujian Atterberg Limit Subgrade Dengan Variasi \% ABKS}

Berikut ini pada Tabel 9 dijelaskan hasil pengujian dari Atterberg Limit Subgrade dengan variasi persentase ABKS.
Tabel 9. Hasil pengujian atterberg limit campuran tanah dengan ABKS

\begin{tabular}{|c|c|c|c|c|}
\hline \multirow{2}{*}{$\begin{array}{c}\text { Masa } \\
\text { Peram }\end{array}$} & \multicolumn{4}{|c|}{ Nilai Plastisitas Indeks (\%) } \\
\cline { 2 - 5 } & $\begin{array}{c}\text { Sampel } \\
1\end{array}$ & $\begin{array}{c}\text { Sampel } \\
2\end{array}$ & $\begin{array}{c}\text { Sampel } \\
3\end{array}$ & $\begin{array}{c}\text { Sampel } \\
4\end{array}$ \\
\hline 0 & 35,57 & 30,15 & 29,55 & 26,25 \\
\hline 3 & - & 29,54 & 28,09 & 26,12 \\
\hline 7 & - & 28,78 & 27,75 & 24,93 \\
\hline
\end{tabular}

Keterangan:

Sampel $1=$ Tanah Asli

Sampel $2=4 \%$ ABKS $+100 \%$ Tanah

Sampel $3=6 \%$ ABKS $+100 \%$ Tanah

Sampel $4=8 \%$ ABKS $+100 \%$ Tanah

Berdasarkan hasil pengujian Atterberg limit Subgrade dengan variasi persentase ABKS yang sudah didapatkan, bahwa untuk nilai PI (Plasticity Index) yang diharapkan adalah nilai PI $<28 \%$ atau masuk ke dalam golongan tanah yang memiliki tingkat pengembangan sedang. Berdasarkan harapan yang ingin dicapai bahwa persentase ABKS yang akan digunakan adalah 8\% ABKS, dikarenakan semua nilai PI yang didapatkan $<28 \%$.

\section{Hasil Pengujian Karakteristik Subgrade Campuran}

Pada bagian ini dijelaskan hasil pengujian karakteristik Subgrade campuran dengan bahan stabilisasi (baik secara kimia, fisik dan mekanis), Berikut penjelasannya:

\section{1) Hasil Pengujian dari CEC (Cation Exchange Capacity)}

Berikut pada Tabel 10 dijelaskan hasil pengujian dari karakteristik kimia Subgrade campuran berdasarkan pengujian CEC. 
Tabel 10. Karakteristik Kimia Subgrade Campuran (Pengujian CEC)

\begin{tabular}{|c|c|c|c|c|c|c|}
\hline \multirow{3}{*}{ Unsur } & \multirow{3}{*}{ Sat. } & \multicolumn{5}{|c|}{ Kandungan CEC pada } \\
\hline & & \multicolumn{5}{|c|}{ Campuran } \\
\hline & & 1 & 2 & 3 & 4 & 5 \\
\hline Ca-dd & \multirow{3}{*}{$\begin{array}{l}\mathrm{Me} / \\
100 \mathrm{~g}\end{array}$} & 13,13 & 25,4 & 26,89 & 24,1 & 21,98 \\
\hline $\mathrm{Na}-\mathrm{dd}$ & & 1,16 & 0,68 & 0,63 & 0,99 & 1,14 \\
\hline K-dd & & 0,37 & 3,99 & 4,37 & 3,58 & 3,12 \\
\hline
\end{tabular}

Keterangan:

Campuran 1 = Tanah Asli

Campuran $2=0 \% \mathrm{SC}+8 \%$ ABKS $+100 \%$ Tanah

Campuran $3=3 \% \mathrm{SC}+8 \%$ ABKS $+100 \%$ Tanah

Campuran $4=6 \% \mathrm{SC}+8 \% \mathrm{ABKS}+100 \%$ Tanah

Campuran $5=9 \%$ SC $+8 \%$ ABKS $+100 \%$ Tanah

Berdasarkan hasil pengujian CEC campuran yang sudah dijelaskan pada Tabel 10, maka dapat disimpulkan bahwa:

- Nilai kation Ca-dd dan K-dd yang optimum terdapat pada campuran 3 yaitu berurutan sebesar 26,89 Me/ 100g dan 4,37 Me/ $100 \mathrm{~g}$

- Nilai kation Na-dd yang optimum terdapat pada campuran 1 yaitu sebesar $1,16 \mathrm{Me} /$ $100 \mathrm{~g}$.

2) Hasil Pengujian Karakteristik Fisik Subgrade Campuran

Berikut pada Tabel 11 dijelaskan hasil pengujian dari karakteristik fisik Subgrade campuran
Tabel 11. Karakteristik Fisik Subgrade Campuran

\begin{tabular}{|l|c|c|c|c|c|c|}
\hline \multirow{2}{*}{$\begin{array}{l}\text { Index } \\
\text { Properties }\end{array}$} & \multirow{3}{*}{ Sat } & \multicolumn{5}{|c|}{ Nilai pada } \\
\cline { 3 - 7 } & & $\mathbf{1}$ & $\mathbf{2}$ & $\mathbf{3}$ & $\mathbf{4}$ & $\mathbf{5}$ \\
\cline { 3 - 7 } & & 28,07 & 26,61 & 30,07 & 31,08 & 32,57 \\
\hline Plastic limit & $\%$ & 63,64 & 52,86 & 53,46 & 51,10 & 49,71 \\
\hline Liquid limit & $\%$ & 35,57 & 26,25 & 23,39 & 20,02 & 17,14 \\
\hline $\begin{array}{l}\text { Plasticity } \\
\text { Index }\end{array}$ & $\%$ & & & & \\
\hline Kealtifan & - & 1,34 & 0,99 & 0,38 & 0,76 & 0,65 \\
\hline
\end{tabular}

Berdasarkan hasil pengujian karakteristik fisik subgrade campuran yang sudah dijelaskan pada Tabel 11, maka dapat disimpulkan bahwa pada campuran 5 dapat menurunkan Plasticity Index sebesar 51,81\% dari kondisi Plasticity Index campuran 1

3) Hasil Pengujian Karakteristik Mekanis

Subgrade Campuran

Berikut pada Tabel 12 dijelaskan hasil pengujian dari karakteristik Mekanis Subgrade campuran

Tabel 12. Karakteristik Mekanis Subgrade Campuran

\begin{tabular}{|c|c|c|c|c|c|c|}
\hline \multirow{3}{*}{$\begin{array}{l}\text { Technical } \\
\text { Properties }\end{array}$} & \multirow{3}{*}{ Sat. } & \multicolumn{5}{|c|}{ Nilai pada } \\
\hline & & \multicolumn{5}{|c|}{ Campuran } \\
\hline & & 1 & 2 & 3 & 4 & 5 \\
\hline $\begin{array}{ll}\text { Berat } & \text { Isi } \\
\text { Kering } & \end{array}$ & $\begin{array}{c}\text { grlc } \\
\mathrm{m}^{3}\end{array}$ & 1,45 & 1,47 & 1,48 & 1,49 & 1,53 \\
\hline $\begin{array}{l}\text { Kadar air } \\
\text { Opt. }\end{array}$ & $\%$ & 26,7 & 25,0 & 24,3 & 23,0 & 21,8 \\
\hline $\begin{array}{l}\text { CBR } \\
\text { UnSoaked }\end{array}$ & $\%$ & 3,39 & 5,81 & 7,94 & 9,32 & 10,7 \\
\hline CBR Soaked & $\%$ & 0,71 & 2,76 & 3,91 & 4,48 & 5,14 \\
\hline $\begin{array}{l}\text { CBR Peram } \\
0 \text { Hari }\end{array}$ & $\%$ & - & 5,76 & 7,81 & 8,85 & 10,5 \\
\hline $\begin{array}{l}\text { CBR Peram } \\
3 \text { Hari }\end{array}$ & $\%$ & - & 7,51 & 9,97 & 10,2 & 11,8 \\
\hline
\end{tabular}

KAJIAN PERBAIKAN SUBGRADE DARI TANAH EKSPANSIF MENGGUNAKAN SPENT CATALYST RCC 15 DAN ABU BATOK KELAPA SAWIT Totok Hermawan, Syahril 


\begin{tabular}{|l|c|c|c|c|c|c|}
\hline $\begin{array}{l}\text { CBR Peram } \\
\text { 7 Hari }\end{array}$ & $\%$ & - & 8,74 & 11,0 & 11,8 & 12,9 \\
\hline $\begin{array}{l}\text { CBR Peram } \\
\text { 14 Hari }\end{array}$ & $\%$ & - & 9,51 & 11,6 & 12,5 & 14,1 \\
\hline $\begin{array}{l}\text { CBR Soaked } \\
\text { 4 Hari }\end{array}$ & $\%$ & - & 4,21 & 5,01 & 6,25 & 7,53 \\
\hline $\begin{array}{l}\text { Permeabilitas } \\
\mathrm{cm} /\end{array}$ & $\begin{array}{c}1,3 \mathrm{x} \\
10^{-4}\end{array}$ & $\begin{array}{c}3,0 \mathrm{x} \\
10^{-3}\end{array}$ & $\begin{array}{c}3,5 \mathrm{x} \\
10^{-3}\end{array}$ & $\begin{array}{c}4,3 \mathrm{x} \\
10^{-3}\end{array}$ & $\begin{array}{c}6,3 \mathrm{x} \\
10^{-3}\end{array}$ \\
\hline $\begin{array}{l}\text { Swelling } \\
\text { Potential }\end{array}$ & $\%$ & 6,37 & 5,99 & 4,96 & 4,15 & 3,89 \\
\hline $\begin{array}{l}\text { Swelling } \\
\text { Pressure }\end{array}$ & $\begin{array}{l}\mathrm{kg} / \mathrm{c} \\
\mathrm{m}^{2}\end{array}$ & 4,41 & 3,38 & 3,21 & 3,08 & 2,76 \\
\hline
\end{tabular}

Untuk memudahkan memahami hasil dari Tabel 12 tersebut, berikut disajikan penjelasan hasil perubahan nilai dari setiap pengujian karakteristik mekanis campuran menggunakan grafik, yaitu sebagai berikut:

a) Hasil perubahan nilai berat isi kering dan kadar air optimum sesuai Gambar 4 dan Gambar 5 berikut ini:

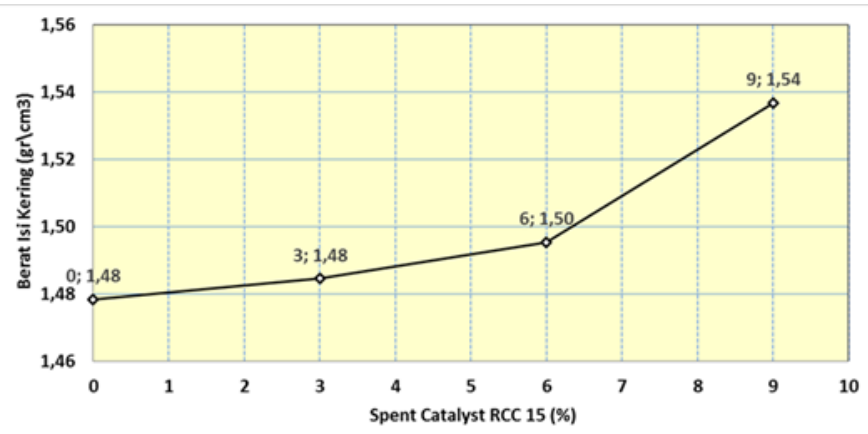

Gambar 4. Berat isi kering terhadap \% Spent Catalyst RCC 15

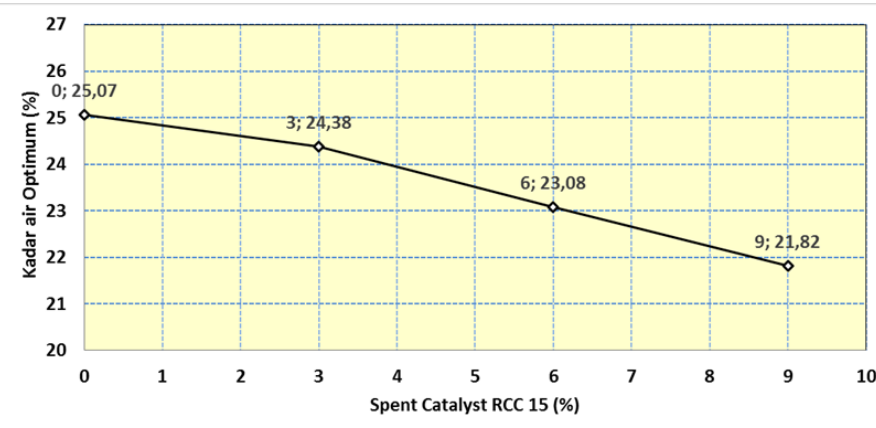

Gambar 5. Kadar air optimum terhadap \% Spent Catalyst RCC 15

Berdasarkan hasil pengujian berat isi kering dan kadar air optimum, maka dapat disimpulkan bahwa:

- Berat isi kering mengalami peningkatan nilai sebesar $5,64 \%$ pada campuran 5 dari kondisi campuran 1

- Kadar air optimum mengalami penurunan nilai sebesar $18,56 \%$ pada campuran 5 dari kondisi campuran 1

b) Hasil perubahan nilai CBR Unsoaked dan CBR Soaked sesuai Gambar 6 berikut ini:

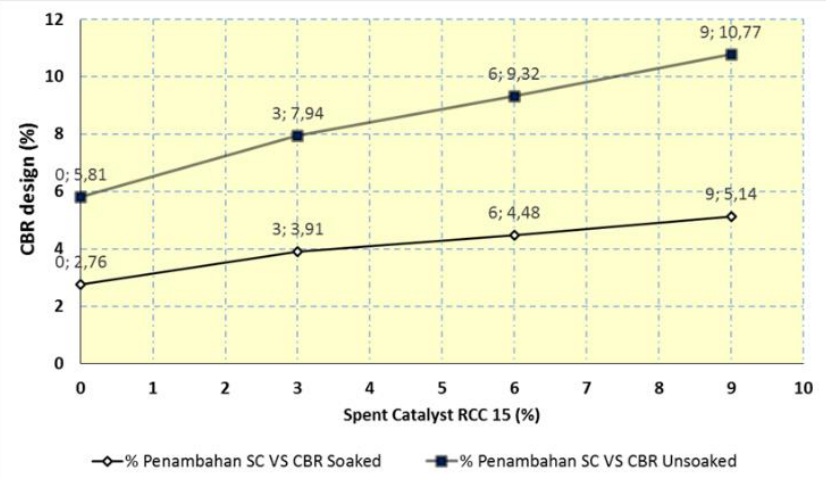

Gambar 6. CBR Unsoaked dan Soaked terhadap $\%$ Spent Catalyst RCC 15

Berdasarkan hasil pengujian CBR Unsoaked dan Soaked, maka dapat disimpulkan bahwa:

- CBR Unsoaked mengalami peningkatan nilai sebesar $217,7 \%$ pada campuran 5 dari kondisi campuran 1

- CBR Soaked mengalami peningkatan nilai sebesar $623,9 \%$ pada campuran 5 dari kondisi campuran 1

c) Hasil perubahan nilai CBR peram secara keseluruhan sesuai Gambar 7 berikut ini:

KAJIAN PERBAIKAN SUBGRADE DARI TANAH EKSPANSIF MENGGUNAKAN SPENT CATALYST RCC 15 DAN ABU BATOK KELAPA SAWIT Totok Hermawan, Syahril 


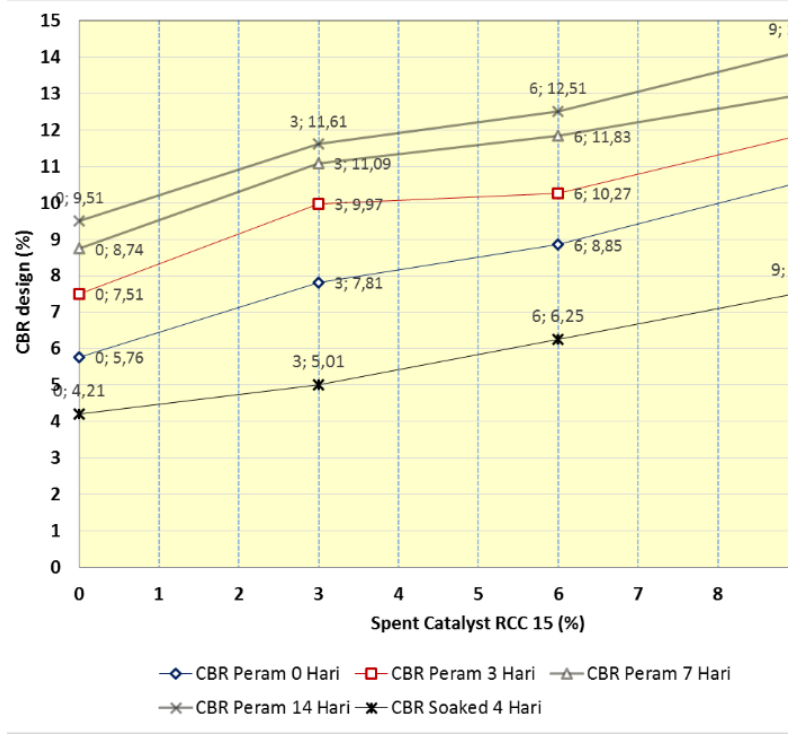

Gambar 7. CBR peram keseluruhan terhadap \% Spent Catalyst RCC 15

Berdasarkan hasil pengujian CBR peram secara keseluruhan, maka dapat disimpulkan bahwa CBR Peram 0 hari, 3 hari, 7 hari dan 14 hari mengalami peningkatan nilai berurutan sebesar $83,33 \%, 57,79 \%, 48,28 \%$ dan $48,58 \%$ pada campuran 5 dari kondisi campuran 2

d) Hasil perubahan nilai Permeabilitas, sesuai Gambar 8 berikut ini:

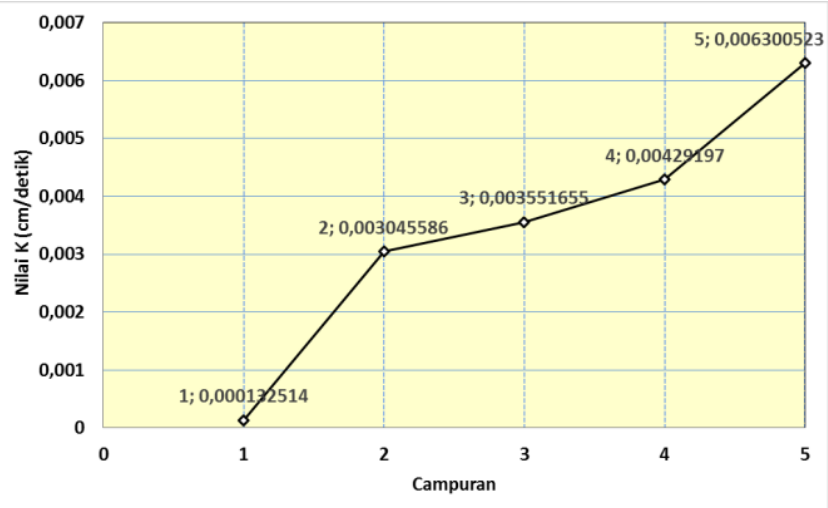

Gambar 8. Permeabilitas dari beberapa Campuran

e) Hasil perubahan nilai Swelling Potential dan Swelling Pressure, sesuai Gambar 9 dan Gambar 10 berikut ini:

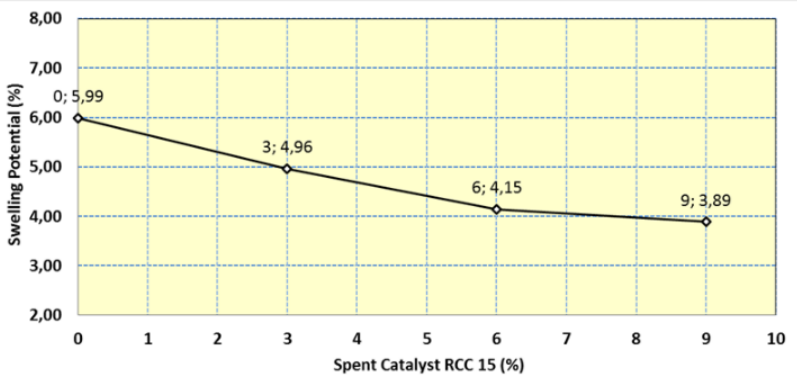

Gambar 9. Swelling Potential terhadap \% Spent Catalyst RCC 15

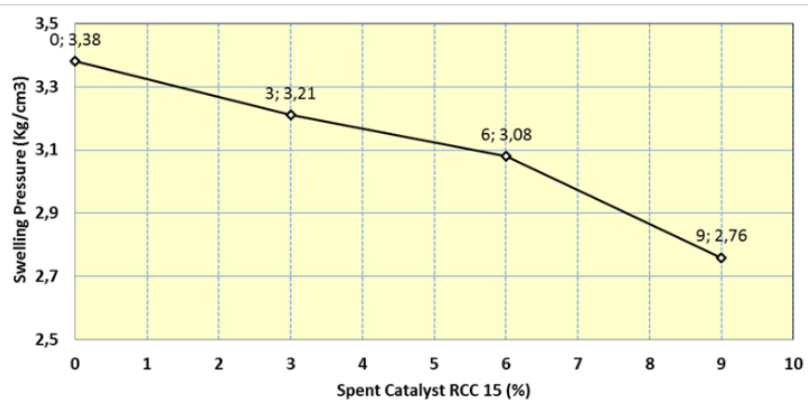

Gambar 10. Swelling Pressure terhadap \% Spent Catalyst RCC 15

Berdasarkan hasil pengujian Swelling Potential dan Swelling Pressure, maka dapat disimpulkan bahwa:

- Swelling Potential mengalami penurunan nilai sebesar $38,99 \%$ pada campuran 5 dari kondisi campuran 1

- Swelling Pressure mengalami penurunan nilai sebesar $37,42 \%$ pada campuran 5 dari kondisi campuran 1

\section{E. Hasil Pengolahan Data Secara Statistik}

Sebelum membahas mengenai hasil pengolahan data secara statistik, berikut ini pada Tabel 13 dijelaskan mengenai nilai untuk variabel (variabel terikat dan variabel bebas) yang digunakan 
Tabel 13. Nilai untuk variabel yang digunakan dalam Pengolahan Statistik

\begin{tabular}{|l|c|c|c|c|l|}
\hline \multicolumn{1}{|c|}{ Variabel } & \multicolumn{4}{|c|}{ Nilai } & Sat. \\
\hline $\begin{array}{l}\text { Bahan } \\
\text { Stabilisasi }\end{array}$ & 0 & 3 & 6 & 9 & $\%$ \\
\hline $\begin{array}{l}\text { Plasticity } \\
\text { Index }\end{array}$ & 26,2 & 23,3 & 20,0 & 17,1 & $\%$ \\
\hline $\begin{array}{l}\text { Swelling } \\
\text { Pressure }\end{array}$ & 3,38 & 3,21 & 3,08 & 2,76 & $\begin{array}{l}\mathrm{Kg} / \\
\mathrm{cm}^{2}\end{array}$ \\
\hline $\begin{array}{l}\text { Swelling } \\
\text { Potential }\end{array}$ & 5,99 & 4,96 & 4,15 & 3,89 & $\%$ \\
\hline $\begin{array}{l}\text { CBR } \\
\text { Unsoaked }\end{array}$ & 5,81 & 7,94 & 9,32 & 10,7 & $\%$ \\
\hline $\begin{array}{l}\text { CBR } \\
\text { Soaked }\end{array}$ & 2,76 & 3,91 & 4,48 & 5,14 & $\%$ \\
\hline $\begin{array}{l}\text { Kadar Air } \\
\text { Optimum }\end{array}$ & 25,0 & 24,3 & 23,1 & 21,8 & $\%$ \\
\hline $\begin{array}{l}\text { Berat Isi } \\
\text { Kering }\end{array}$ & 1,47 & 1,48 & 1,49 & 1,53 & $\begin{array}{l}\text { gr/c } \\
\mathrm{m}^{3}\end{array}$ \\
\hline
\end{tabular}

Pada bagian ini dijelaskan secara singkat mengenai hasil pengolahan data secara statistik menggunakan perangkat lunak SPSS seperti yang ditunjukan pada Tabel 14 berikut ini
Tabel 14. Hasil Pengolahan Data Statistik Secara Keseluruhan

\begin{tabular}{|c|c|c|c|c|c|c|}
\hline \multirow{2}{*}{ No } & \multicolumn{2}{|c|}{ Variabel } & \multicolumn{4}{|c|}{ Nilai } \\
\hline & $\mathbf{Y}$ & $\mathbf{X}$ & $\mathbf{R}$ & $\begin{array}{c}\text { F } \\
\text { Hitung }\end{array}$ & $\begin{array}{c}\text { F } \\
\text { Tabel }\end{array}$ & $\begin{array}{c}\text { Persamaan } \\
\text { Statistik }\end{array}$ \\
\hline 1 & $\begin{array}{l}\text { Kode } \\
\text { A }\end{array}$ & $\begin{array}{l}\text { Kede } \\
\text { B }\end{array}$ & 0,99 & 1881,22 & 18,51 & $\begin{array}{l}Y=-1,0233+ \\
26,305\end{array}$ \\
\hline 2 & $\begin{array}{l}\text { Kode } \\
\text { A }\end{array}$ & $\begin{array}{l}\text { Kode } \\
\text { C }\end{array}$ & 0,96 & 47,89 & 18,51 & $\begin{array}{l}Y=-0,0663 X \\
+3,406\end{array}$ \\
\hline 3 & $\begin{array}{l}\text { Kode } \\
\text { A }\end{array}$ & $\begin{array}{l}\text { Kode } \\
\text { D }\end{array}$ & 0,94 & 32,90 & 18,51 & $\begin{array}{l}Y=-0,237 X \\
+5,814\end{array}$ \\
\hline 4 & $\begin{array}{l}\text { Kode } \\
\text { A }\end{array}$ & $\begin{array}{l}\text { Kode } \\
\text { F }\end{array}$ & 0,97 & 72,08 & 18,51 & $\begin{array}{l}Y=0,257 \mathrm{X}+ \\
2,916\end{array}$ \\
\hline 5 & $\begin{array}{l}\text { Kode } \\
\text { A }\end{array}$ & $\begin{array}{l}\text { Kode } \\
\text { E }\end{array}$ & 0,98 & 177,18 & 18,51 & $\begin{array}{l}Y=0,542 X+ \\
6,021\end{array}$ \\
\hline 6 & $\begin{array}{l}\text { Kode } \\
\text { A }\end{array}$ & $\begin{array}{l}\text { Kode } \\
\text { G }\end{array}$ & 0,99 & 6498 & 18,51 & $\begin{array}{l}Y=-0.0386 X \\
+0.9932\end{array}$ \\
\hline 7 & $\begin{array}{l}\text { Kode } \\
\text { E }\end{array}$ & $\begin{array}{l}\text { Kode } \\
\text { B }\end{array}$ & 0,98 & 125,20 & 18,51 & $\begin{array}{l}Y=-1,864 x \\
+37,647\end{array}$ \\
\hline 8 & $\begin{array}{l}\text { Kode } \\
\text { D }\end{array}$ & $\begin{array}{l}\text { Kode } \\
\text { B }\end{array}$ & 0,94 & 33,63 & 18,51 & $\begin{array}{l}Y=4.075 X+ \\
2,353\end{array}$ \\
\hline 9 & $\begin{array}{l}\text { Kode } \\
\text { C }\end{array}$ & $\begin{array}{l}\text { Kode } \\
\text { B }\end{array}$ & 0,95 & 39,80 & 18,51 & $\begin{array}{l}Y=14,757 X \\
-24,156\end{array}$ \\
\hline 10 & $\begin{array}{l}\text { Kode } \\
\text { F }\end{array}$ & $\begin{array}{l}\text { Kode } \\
\text { E }\end{array}$ & 0,99 & 560,93 & 18,51 & $\begin{array}{l}Y=2.088 X- \\
0,044\end{array}$ \\
\hline 11 & $\begin{array}{l}\text { Kode } \\
\text { I }\end{array}$ & $\begin{array}{l}\text { Kode } \\
\mathrm{H}\end{array}$ & 0,91 & 20,21 & 18,51 & $\begin{array}{l}Y=-52,241 X \\
+101.550\end{array}$ \\
\hline
\end{tabular}

Keterangan:

$\mathrm{X}=$ Variabel Bebas

$\mathrm{Y} \quad=$ Variabel Terikat

$\mathrm{R}=$ Koefisien Relasi

Kode A = Bahan Stabilisasi

Kede B = Plasticity Index

Kode C $=$ Swelling Pressure

Kode $\mathrm{D}=$ Swelling Potential

Kode $\mathrm{E}=\mathrm{CBR}$ Unsoaked

Kode F $=$ CBR Soaked

Kode $\mathrm{G}=$ Tingkat Keaktifan

Kode $\mathrm{H}=$ Kadar Air Optimum

KAJIAN PERBAIKAN SUBGRADE DARI TANAH EKSPANSIF MENGGUNAKAN SPENT CATALYST RCC 15 DAN ABU BATOK KELAPA SAWIT Totok Hermawan, Syahril 
Kode I = Berat Isi Kering

Untuk mempermudah memahami penjelasan berdasarkan Tabel 14, berikut ini dijelaskan arti setiap kategori yang ada:

- Koefisien Relasi

Berdasarkan nilai koefisien Relasi yang di dapat menyatakan bahwa korelasi dari semua variabel statistik yang dibuat memiliki hubungan yang sangat tinggi dikarenakan nilai $\mathrm{R}$ yang didapat terletak Siantar 0,75-0,99.

- F Hitung dan F Tabel

Berdasarkan nilai F Hitung dan F Tabel yang di dapat menyatakan bahwa korelasi dari semua variabel statistik yang dibuat memiliki arti atau berarti secara statistik dikarenakan F Hitung > F Tabel.

\section{Pembahasan}

\section{A. Ketercapaian Subgrade Campuran Sebagai Standar Minimal Lapisan Perkerasan Jalan}

Pada bagian ini dijelaskan mengenai ketercapaian Karakteristik Subgrade Campuran terhadap standar minimal nilai sebagai lapisan perkerasan jalan, berikut penjelasannya:

1) Ketercapaian Subgrade Campuran

2) Berdasarkan Sifat Fisik Sebagai Standar Minimal Lapisan Perkerasan Jalan

Pada Tabel 15 dijelaskan mengenai hubungan antara perubahan Karakteristik fisik Subgrade campuran bahan stabilisasi terhadap standar minimal lapis perkerasan jalan.

Tabel 15. Perubahan Sifat Fisik Subgrade

\begin{tabular}{|l|c|c|c|c|c|c|c|}
\hline \multirow{2}{*}{$\begin{array}{c}\text { Index } \\
\text { Properties }\end{array}$} & \multirow{5}{*}{ Sat } & \multicolumn{5}{|c|}{ Nilai pada } & \multirow{2}{*}{$\begin{array}{c}\text { Standar } \\
\text { Nilai }\end{array}$} \\
\cline { 3 - 6 } & & $\mathbf{1}$ & $\mathbf{2}$ & $\mathbf{3}$ & $\mathbf{4}$ & $\mathbf{5}$ & \\
\cline { 3 - 7 } & $\%$ & 35,5 & 26,2 & 23,3 & 20,0 & 17,1 & $<18,0$ \\
\hline $\begin{array}{l}\text { Plasticity } \\
\text { Index }\end{array}$ & $\%$ & 1,34 & 0,99 & 0,88 & 0,76 & 0,65 & $<1,25$ \\
\hline Keaktifan & - & & & \\
\hline
\end{tabular}

Keterangan:

Campuran 1 = Tanah Asli

Campuran $2=0 \% \mathrm{SC}+8 \%$ ABKS $+100 \%$

Tanah

Campuran $3=3 \%$ SC $+8 \%$ ABKS $+100 \%$

Tanah

Campuran $4=6 \%$ SC $+8 \%$ ABKS $+100 \%$ Tanah

Campuran $5=9 \%$ SC $+8 \%$ ABKS $+100 \%$ Tanah

Ketercapaian Standar Minimal Nilai

$=$ Sebagai lapisan Perkerasan Jalan

- Tidak Tercapai Standar Minimal Nilai

$=$ Sebagai lapisan Perkerasan Jalan

Berdasarkan perbaikan Subgrade yang dilakukan dengan menggunakan bahan stabilisasi, didapatkan suatu ketercapaian Subgrade berdasarkan sifat fisik sebagai lapisan perkerasan jalan yaitu:

- Untuk PI tercapai pada Subgrade Campuran 5

- Untuk AC tercapai pada Subgrade Campuran 2, 3, 4, dan 5

3) Ketercapaian Subgrade Campuran Berdasarkan Sifat Mekanis Sebagai Standar Minimal Lapisan Perkerasan Jalan

Pada Tabel 16 dijelaskan mengenai hubungan antara perubahan Karakteristik mekanis Subgrade campuran bahan stabilisasi terhadap standar minimal lapis perkerasan jalan.

Tabel 16. Perubahan Sifat Mekanis Subgrade

\begin{tabular}{|l|c|c|c|c|c|c|}
\hline \multirow{2}{*}{$\begin{array}{l}\text { Technical } \\
\text { Properties }\end{array}$} & \multirow{2}{*}{ Sat. } & \multicolumn{4}{|c|}{ Nilai pada } & \multirow{4}{*}{$\begin{array}{c}\text { Standar } \\
\text { Nilai }\end{array}$} \\
\cline { 3 - 6 } & & $\mathbf{2}$ & $\mathbf{3}$ & $\mathbf{4}$ & $\mathbf{5}$ & \\
\cline { 3 - 6 } $\begin{array}{l}\text { CBR } \\
\text { Unsoaked }\end{array}$ & $\%$ & 5,81 & 7,94 & 9,32 & 10,7 & $\geq 6$ \\
\hline $\begin{array}{l}\text { CBR } \\
\text { Soaked }\end{array}$ & $\%$ & 2,76 & 3,91 & 4,48 & 5,14 & $\geq 6$ \\
\hline
\end{tabular}

KAJIAN PERBAIKAN SUBGRADE DARI TANAH EKSPANSIF MENGGUNAKAN SPENT CATALYST RCC 15 DAN ABU BATOK KELAPA SAWIT Totok Hermawan, Syahril 


\begin{tabular}{|l|c|c|c|c|c|c|}
\hline $\begin{array}{l}\text { CBR } \\
\text { Peram } \\
\text { Hari }\end{array}$ & $\%$ & 5,76 & 7,81 & 8,85 & 10,5 & $\geq 6$ \\
\hline $\begin{array}{l}\text { CBR } \\
\text { Peram } \\
\text { Hari }\end{array}$ & $\%$ & 7,51 & 9,97 & 10,2 & 11,8 & $\geq 6$ \\
\hline $\begin{array}{l}\text { CBR } \\
\text { Peram } \\
\text { Hari }\end{array}$ & $\%$ & 8,74 & 11,0 & 11,8 & 12,9 & $\geq 6$ \\
\hline $\begin{array}{l}\text { CBR } \\
\text { Peram 14 } \\
\text { Hari }\end{array}$ & $\%$ & 9,51 & 11,6 & 12,5 & 14,1 & $\geq 6$ \\
\hline $\begin{array}{l}\text { Swelling } \\
\text { Potential }\end{array}$ & $\%$ & 5,99 & 4,96 & 4,15 & 3,89 & $\leq 5$ \\
\hline $\begin{array}{l}\text { Swelling } \\
\text { Pressure }\end{array}$ & $\mathrm{Kg} /$ \\
$\mathrm{cm} 2$ & 3,38 & 3,21 & 3,08 & 2,76 & $\leq 4$ \\
\hline
\end{tabular}

Keterangan:

Campuran 1 = Tanah Asli

Campuran $2=0 \% \mathrm{SC}+8 \% \mathrm{ABKS}+100 \%$ Tanah

Campuran $3=3 \%$ SC $+8 \%$ ABKS $+100 \%$ Tanah

Campuran $4=6 \% \mathrm{SC}+8 \%$ ABKS $+100 \%$ Tanah

Campuran $5=9 \%$ SC $+8 \%$ ABKS $+100 \%$ Tanah

Ketercapaian Standar Minimal Nilai

$=$ Sebagai lapisan Perkerasan Jalan

- Tidak Tercapai Standar Minimal Nilai

Sebagai lapisan Perkerasan Jalan

Berdasarkan perbaikan Subgrade yang dilakukan dengan menggunakan bahan stabilisasi, didapatkan suatu ketercapaian Subgrade berdasarkan sifat mekanis sebagai lapisan perkerasan jalan yaitu:

- Untuk CBR Unsoaked tercapai pada Subgrade Campuran 3, 4, 5

- Untuk CBR Soaked tidak tercapai

- Untuk CBR Peram 0 Hari tercapai pada Subgrade Campuran 3, 4, 5

- Untuk CBR Peram (3, 7 dan 14) Hari tercapai pada Subgrade Campuran 2, 3, 4, 5
- Untuk Swelling Potential tercapai pada Subgrade Campuran 3, 4, 5

- Untuk Swelling Pressure tercapai pada Subgrade Campuran 2, 3, 4, 5

\section{B. Desain Campuran Bahan Stabilisasi Berdasarkan Persamaan Statistik}

1. Terhadap Standar Karakteristik Subgrade Lapisan Perkerasan Jalan

Berikut ini pada Tabel 17 ditampilkan mengenai hasil persamaan statistik antara bahan stabilisasi dengan karakteristik subgrade.

Tabel 17. Persamaan statistik antara bahan stabilisasi dengan karakteristik subgrade

\begin{tabular}{|c|c|c|c|}
\hline \multirow[b]{2}{*}{ No } & \multicolumn{2}{|c|}{ Variabel Statistik } & \multirow[b]{2}{*}{$\begin{array}{l}\text { Persamaan } \\
\text { Statistik }\end{array}$} \\
\hline & $\begin{array}{l}\text { Variabel } \\
\text { Bebas }(\mathbf{X})\end{array}$ & $\begin{array}{l}\text { Variabel } \\
\text { Terikat } \\
\text { (Y) }\end{array}$ & \\
\hline 1 & $\begin{array}{l}\text { Bahan } \\
\text { Stabilisasi }\end{array}$ & $\begin{array}{l}\text { Plasticity } \\
\text { Index }\end{array}$ & $\begin{array}{l}Y= \\
1.0233 \mathrm{X} \\
26.305\end{array}$ \\
\hline 2 & $\begin{array}{l}\text { Bahan } \\
\text { Stabilisasi }\end{array}$ & $\begin{array}{l}\text { Swelling } \\
\text { Pressure }\end{array}$ & $\begin{array}{l}Y= \\
0.0663 \mathrm{X} \\
3.406\end{array}$ \\
\hline 3 & $\begin{array}{l}\text { Bahan } \\
\text { Stabilisasi }\end{array}$ & $\begin{array}{l}\text { Swelling } \\
\text { Potential }\end{array}$ & $\begin{array}{l}Y=-0.237 X \\
+5.814\end{array}$ \\
\hline 4 & $\begin{array}{l}\text { Bahan } \\
\text { Stabilisasi }\end{array}$ & $\begin{array}{l}\text { CBR } \\
\text { Soaked }\end{array}$ & $\begin{array}{l}Y=0.257 \mathrm{X} \\
+2.916\end{array}$ \\
\hline 5 & $\begin{array}{l}\text { Bahan } \\
\text { Stabilisasi }\end{array}$ & $\begin{array}{l}\text { CBR } \\
\text { Unsoaked }\end{array}$ & $\begin{array}{l}Y=0.542 X \\
+6.021\end{array}$ \\
\hline 6 & $\begin{array}{l}\text { Bahan } \\
\text { Stabilisasi }\end{array}$ & $\begin{array}{l}\text { Tingkat } \\
\text { Keaktifan }\end{array}$ & $\begin{array}{l}Y= \\
0.0386 \mathrm{X} \\
0.9932\end{array}$ \\
\hline
\end{tabular}

Berdasarkan hasil persamaan statistik sesuai Tabel 17 dapat dibuat suatu desain campuran bahan stabilisasi yang dapat digunakan untuk mencari karakteristik subgrade sebagai standar lapisan perkerasan jalan, seperti yang dijelaskan pada Tabel 18 dan Tabel 19 sebagai berikut:

KAJIAN PERBAIKAN SUBGRADE DARI TANAH EKSPANSIF MENGGUNAKAN SPENT CATALYST RCC 15 DAN ABU BATOK KELAPA SAWIT Totok Hermawan, Syahril 
Tabel 18. Desain ke-1 campuran bahan stabilisasi berdasarkan persamaan statistic

\begin{tabular}{|c|c|c|c|c|c|c|c|}
\hline \multicolumn{2}{|c|}{$\begin{array}{c}\text { Variabel } \\
\text { Bebas }\end{array}$} & \multirow{2}{*}{$\begin{array}{c}\text { Nilai } \\
9\end{array}$} & \multicolumn{2}{|c|}{$\begin{array}{l}\text { Variabel } \\
\text { Terikat }\end{array}$} & \multirow{2}{*}{$\begin{array}{l}\text { Nilai } \\
17.10\end{array}$} & \multirow{2}{*}{$\begin{array}{c}\begin{array}{c}\text { Standar } \\
\text { Nilai } \\
\text { Variabel } \\
\text { Terikat }\end{array} \\
<18\end{array}$} & \multirow{2}{*}{$\begin{array}{c}\text { Ket. } \\
\mathrm{OK}\end{array}$} \\
\hline $\mathrm{X}$ & $\begin{array}{l}\text { Bahan } \\
\text { Stabilisasi }\end{array}$ & & $\mathrm{Y}$ & $\begin{array}{l}\text { Plasticity } \\
\text { Index }\end{array}$ & & & \\
\hline $\mathrm{x}$ & $\begin{array}{l}\text { Bahan } \\
\text { Stabilisasi }\end{array}$ & 9 & $\mathrm{Y}$ & $\begin{array}{l}\text { Swelling } \\
\text { Pressure }\end{array}$ & 2.81 & $<4$ & $\mathrm{OK}$ \\
\hline $\mathrm{X}$ & $\begin{array}{l}\text { Bahan } \\
\text { Stabilisasi }\end{array}$ & 9 & $\mathrm{Y}$ & $\begin{array}{l}\text { Swelling } \\
\text { Potential }\end{array}$ & 3.68 & $<5$ & $\mathrm{OK}$ \\
\hline $\mathrm{X}$ & $\begin{array}{l}\text { Bahan } \\
\text { Stabilisasi }\end{array}$ & 9 & $\mathrm{Y}$ & $\begin{array}{l}\text { CBR } \\
\text { Soaked }\end{array}$ & 5.23 & $\geq 6$ & $\begin{array}{c}\text { NOT } \\
\mathrm{OK}\end{array}$ \\
\hline $\mathrm{X}$ & $\begin{array}{l}\text { Bahan } \\
\text { Stabilisasi }\end{array}$ & 9 & $\mathrm{Y}$ & $\begin{array}{l}\text { CBR } \\
\text { Unsoaked }\end{array}$ & 10.90 & $\geq 6$ & $\mathrm{OK}$ \\
\hline $\mathrm{X}$ & $\begin{array}{l}\text { Bahan } \\
\text { Stabilisasi }\end{array}$ & 9 & $\mathrm{Y}$ & $\begin{array}{l}\text { Tingkat } \\
\text { Kealtifan }\end{array}$ & 0.65 & $\leq 1.25$ & $\mathrm{OK}$ \\
\hline
\end{tabular}

Berdasarkan hasil desain ke-1 didapatkan salah satu campuran bahan stabilisasi yang belum dapat memenuhi standar karakteristik subgrade terutama pada karakteristik mekanis subgrade yaitu CBR Soaked, sehingga campuran bahan stabilisasi perlu ditambah agar nilai CBR Soaked $\geq 6 \%$ (standar karakteristik subgrade sebagai lapisan perkerasan jalan. Berdasarkan penjelasan sebelumnya maka untuk desain ke-2 campuran bahan stabilisasi yang dipakai adalah 12\%, berikut penjelasannya sesuai Tabel 19 .

Tabel 19. Desain ke-2 campuran bahan stabilisasi berdasarkan persamaan statistik

\begin{tabular}{|c|c|c|c|c|c|c|c|}
\hline \multicolumn{2}{|c|}{ Nariabel Bebas } & \multirow{2}{*}{$\begin{array}{c}\text { Nilai } \\
12\end{array}$} & \multicolumn{2}{|c|}{ Variabel Terikat } & \multirow{2}{*}{$\begin{array}{l}\text { Nilai } \\
14.03\end{array}$} & \multirow{2}{*}{$\begin{array}{c}\begin{array}{c}\text { Standar } \\
\text { Nilai } \\
\text { Variabel } \\
\text { Terikat }\end{array} \\
<18\end{array}$} & \multirow{2}{*}{$\begin{array}{c}\text { Ket. } \\
\mathrm{OK}\end{array}$} \\
\hline $\mathrm{x}$ & $\begin{array}{l}\text { Bahan } \\
\text { Stabilisasi }\end{array}$ & & $\mathrm{Y}$ & Plasticity Index & & & \\
\hline $\mathrm{x}$ & $\begin{array}{l}\text { Bahan } \\
\text { Stabilisasi }\end{array}$ & 12 & $\mathrm{Y}$ & $\begin{array}{l}\text { Swelling } \\
\text { Pressure }\end{array}$ & 2.61 & $<4$ & $\mathrm{OK}$ \\
\hline $\mathrm{x}$ & $\begin{array}{l}\text { Bahan } \\
\text { Stabilisasi }\end{array}$ & 12 & $\mathrm{Y}$ & $\begin{array}{l}\text { Swelling } \\
\text { Potential }\end{array}$ & 2.97 & $<5$ & OK \\
\hline $\mathrm{X}$ & $\begin{array}{l}\text { Bahan } \\
\text { Stabilisasi }\end{array}$ & 12 & $\mathrm{Y}$ & CBR Soaked & 6.00 & $\geq 6$ & $\mathrm{OK}$ \\
\hline $\mathrm{X}$ & $\begin{array}{l}\text { Bahan } \\
\text { Stabilisasi }\end{array}$ & 12 & $\mathrm{Y}$ & CBR Unsoaked & 12.53 & $\geq 6$ & OK \\
\hline $\mathrm{X}$ & $\begin{array}{l}\text { Bahan } \\
\text { Stabilisasi }\end{array}$ & 12 & $\mathrm{Y}$ & $\begin{array}{l}\text { Tingkat } \\
\text { Kealatifan }\end{array}$ & 0.53 & $\leq 1.25$ & $\mathrm{OK}$ \\
\hline
\end{tabular}

Berdasarkan hasil desain ke-2 dengan campuran bahan stabilisasi sebesar 12\% didapatkan semua nilai karakteristik subgrade memenuhi sebagai lapisan perkerasan jalan. Campuran bahan stabilisasi $12 \%$ artinya campuran antara $12 \%$ Spent Catalyt RCC 15 dicampur dengan 8\% Abu Batok Kelapa Sawit.

2. Mencapai Nilai Karakteristik Subgrade Yang Dapat Digunakan Sebagai Lapis Pondasi Bawah

Berdasarkan hasil persamaan statistik dapat dibuat suatu desain campuran bahan stabilisasi yang dapat digunakan untuk mencari karakteristik subgrade yang dapat digunakan sebagai lapis pondasi bawah, seperti yang dijelaskan pada Tabel 20 sebagai berikut:

Tabel 20. Desain ke-3 campuran bahan stabilisasi berdasarkan persamaan statistic

\begin{tabular}{|c|c|c|c|l|c|c|c|}
\hline \multicolumn{2}{|c|}{$\begin{array}{c}\text { Variabel } \\
\text { Bebas }\end{array}$} & Nilai & \multicolumn{1}{|c|}{$\begin{array}{c}\text { Variabel } \\
\text { Terikat }\end{array}$} & Nilai & $\begin{array}{c}\text { Standar } \\
\text { Nilai } \\
\text { Variabel } \\
\text { Terikat }\end{array}$ & Ket. \\
\hline \hline $\mathrm{X}$ & $\begin{array}{l}\text { Bahan } \\
\text { Stabilisasi }\end{array}$ & 25 & $\mathrm{Y}$ & $\begin{array}{l}\text { Plasticity } \\
\text { Index }\end{array}$ & 0.7 & $<10$ & OK \\
\hline $\mathrm{X}$ & $\begin{array}{l}\text { Bahan } \\
\text { Stabilisasi }\end{array}$ & 25 & $\mathrm{Y}$ & $\begin{array}{l}\text { CBR } \\
\text { Unsoaked }\end{array}$ & 20 & $\geq 20$ & OK \\
\hline
\end{tabular}

Berdasarkan hasil desain ke-3 dengan campuran bahan stabilisasi sebesar 25\% didapatkan nilai karakteristik subgrade yang dapat digunakan sebagai lapisan pondasi bawah. Campuran bahan stabilisasi $25 \%$ artinya campuran antara 25\% Spent Catalyt RCC 15 dicampur dengan 8\% Abu Batok Kelapa Sawit.

\section{Pengaruh Stabilisasi Subgrade Terhadap Perkerasan Jalan}

Pada bagian ini dijelaskan mengenai pengaruh stabilisasi Subgrade terhadap perkerasan jalan. Parameter nilai yang digunakan adalah perubahan nilai CBR terhadap daya dukung dan perubahan nilai Swelling terhadap kembang susut Subgrade. Berikut penjelasannya: 
1) Pengaruh Perubahan Nilai CBR (Daya Dukung) Subgrade Terhadap Perkerasan Jalan

a. Berdasarkan Metoda AASHTO 1986 dan Metode Bina Marga 1987.

Bahwa semakin meningkatnya nilai CBR yang didapat dapat mengurangi tebal perkerasan jalan yang akan didesain. Berikut dijelaskan rumus yang menjadi dasar bahwa nilai CBR dapat mempengaruhi tebal lapis perkerasan.

- Berdasarkan metoda AASHTO 1986

- $\mathrm{M}_{\mathrm{R}}=1500 \times \mathrm{CBR}$ (psi)

- Berdasarkan metoda Bina Marga 1987

- $\mathrm{DDT}=4,3 \log \mathrm{CBR}+1,7$

b. Berdasarkan Manual Desain Perkerasan Jalan (2012).

Bahwa semakin meningkatnya nilai CBR yang didapat dapat mengurangi tebal tanah dasar yang harus di treatment, hal ini dapat memberikan efek tidak perlu dilakukan peningkatan terhadap Subgradenya jika nilai CBR > 6\%. Hal ini secara langsung dapat memberikan kemudahan dan kecepatan di dalam melakukan pekerjaan pembangunan struktur perkerasan diatasnya.

2) Pengaruh Perubahan Nilai Swelling (Kembang Susut) Subgrade Terhadap Perkerasan Jalan

a. Menurut Yuliet,dkk (2011).

Bahwa semakin mengecilnya nilai Swelling Pressure (Tekanan Mengambang) dan Swelling Potential (Potensi Mengembang) pada Subgrade akan berdampak terhadap kestabilan struktur perkerasannya diatasnya, hal ini secara langsung dapat mengurangi kerusakan pada perkerasan jalan yang akan di bangun.

b. Berdasarkan Pd T-10-2005-B.

Bahwa semakin mengecil nilai Swelling Pressure (Tekanan Mengembang) Subgrade dapat menambah masa umur layan dari perkerasan jalan, dikarenakan tingkat tekanan mengembang Subgrade dapat mempengaruhi dari kondisi struktur diatas Subgrade.

\section{Kesimpulan}

Berdasarkan hasil pengujian dan pembahasan yang digambarkan dalam tesis ini, dapat disimpulkan sebagai berikut:

1. Terdapat perubahan penurunan kadar air optimum dan kenaikan nilai berat isi kering berurutan sebesar $18,56 \%$ dan $5,64 \%$ pada campuran 5 dari kondisi campuran 1

2. Terdapat perubahan penurunan nilai Plasticity Index sebesar $51,81 \%$ pada campuran 5 dari kondisi campuran 1

3. Terdapat perubahan peningkatan nilai CBR Unsoaked dan Soaked berurutan sebesar $217,7 \%$ dan $623,94 \%$ pada campuran 5 dari kondisi campuran 1

4. Terdapat perubahan peningkatan nilai CBR Peram 0 Hari, 3 Hari, 7 Hari dan 14 Hari sebesar 83,33\%; 57,79\%; 48,28\% dan $48,58 \%$ pada campuran 5 dari kondisi campuran 2

5. Terdapat perubahan penurunan nilai Swelling Potential dan Swelling Pressure berurutan sebesar 38,99\% dan 37,42\% pada campuran 5 dari kondisi campuran 1 .

6. Terdapat perubahan kenaikan nilai Kation Ca-dd dan K-dd berurutan sebesar 67,40\% dan $743,24 \%$ pada campuran 5 dari kondisi campuran 1.

7. Terdapat Trend yang hampir seirama antara peningkatan jumlah campuran bahan stabilisasi dengan hasil dari setiap pengujian, baik itu pengujian secara fisik, mekanis maupun kimiawi.

8. Tercapainya campuran bahan stabilisasi yang dapat digunakan sebagai perbaikan Subgrade pada tanah ekspansif untuk standar minimal Subgrade lapisan perkerasan jalan yaitu untuk:

a) Karakteristik Fisik untuk Plasticity Index tercapai pada campuran $5(8 \%$ ABKS + 9\% SC), Tingkat Keaktifan tercapai pada campuran $2(8 \%$ ABKS + $0 \% \mathrm{SC}$ ).

b) Karakteristik Mekanis untuk CBR Unsoaked, CBR Peram 0 hari dan Swelling Potential tercapai pada campuran $3(8 \%$ ABKS + 3\% SC) sedangkan CBR peram 3 hari, CBR Peram 7 hari, CBR peram 14 hari dan

PUEISI KAJIAN PERBAIKAN SUBGRADE DARI TANAH EKSPANSIF MENGGUNAKAN SPENT CATALYST RCC 15 DAN ABU BATOK KELAPA SAWIT Totok Hermawan, Syahril 
Swelling Pressure tercapai pada campuran $2(8 \% \mathrm{ABKS}+0 \% \mathrm{SC})$.

9. Belum Tercapainya campuran yang optimum antara bahan stabilisasi yang digunakan sebagai perbaikan Subgrade pada tanah ekspansif, dikarenakan trend grafik pengujian (Secara fisik, mekanis) pada campuran 5 (8\% ABKS dan 9\% SC) masih terjadi peningkatan

\section{Daftar Pustaka}

Harianto, Joni, (2003): Penggunaan Sistem Lapis Pndasi Jalan Tanpa Penutup Untuk Jalan Di Pedesaan, Jurusan Teknik Sipil, Fakultas Teknik, Universitas Sumatera Utara

Holtz, R.D., and Giibbs, H.J., (1956): Engineering Properties of ExpansiveClay Transactions, ASCE, Vol.121: pp 641-677.

Manual Desain Perkerasan Jalan 22.2 /KPTS/Db/2012

Pedoman Konstruksi dan Bangunan Pd T-102005-B. (2005): Penanganan tanah ekspansifuntuk konstruksi jalan. Departemen Pekerjaan Umum

Seta, Wijaya, (2010): Perilaku Tanah Ekspansif Yang Dicampur Dengan Pasir Untuk Subgrade, Tesis, Magister Teknik Konsentrasi Transportasi, Universitas Diponegoro

Sudirja, (2008): Pengaruh Penambahan Spent Catalyst pada Stabilisasi Tanah Semen terhadap kembang susut dan Daya Dukung Tanah Ekspansif sebagai Subgrade Jalan, Tesis jurusan Teknik Sipil Universitas Diponegoro, Semarang

Tri Hatmoko, dkk, (2017): Ucs Tanah Lempung Ekspansif Yang Distabilisasi Dengan Abu Ampas Tebu Dan Kapur, Program Studi Teknik Sipil Universitas Atma Jaya Yogyakarta
Yahya, RG, (2015): Kerusakan Jalan Raya Akibat Tanah Mengembang, Jurnal, Universitas Langlangbuana Bandung

Yuliet, dkk, (2011): Uji Potensi Mengembang Pada Tanah Lempung Dengan Metoda Free Swelling Test, Jurnal Teknik Sipil, Universitas Andalas 